\title{
The synergy among stakeholders to develop Pisang Island as marine tourism: The case of underdeveloped area
}

\author{
Sinergitas antar stakeholders dalam pengembangan Pisang Island sebagai \\ wisata bahari: Studi kasus di daerah tertinggal \\ Dian Kagungan \& Devi Yulianti \\ Department of Public Administration, Faculty of Social and Political Sciences, Universitas Lampung \\ Address: Jalan Prof. Dr. Soemantri Brojonegoro Nomor 1, Bandarlampung 35145 \\ E-mail: dian.kagungan@,fisip.unila.ac.id \& devi.yulianti@fisip.unila.ac.id \\ Phone: 081273376677
}

\begin{abstract}
This research is motivated by the problems that arise from the implementation of the strategy of tourism development and a creative economy in Pisang Island of Pesisir Barat District, Lampung Province. The purpose of this research is to analyze the synergy between various parties in the development of marine tourism in Pisang Island. The research uses descriptive and qualitative approaches. The data collection techniques in use include interviews, documentation, and observation. Data analysis is carried out through data reduction, data display, and conclusion. The results showed that the strategy of marine tourism development in Pisang Island was not well implemented as a result of the lack of co-operation between government, society, and investors. The government was the pioneer of the construction of facilities, in both the main facilities and infrastructure, for potential investors who would invest their capital. As a result of this research, the recommendations to be made are that local governments should increase extension activities (such as training and community education) to create community awareness. Furthermore, private sectors could invest their capital by pioneering the development of facilities that do not yet exist needed near tourism attractions.
\end{abstract}

Keywords: the synergy; stakeholders; marine tourism; underdeveloped area

\begin{abstract}
Abstrak
Penelitian ini dilatarbelakangi oleh permasalahan yang muncul dari ketidakmaksimalan pelaksanaan rencana strategi pengembangan pariwisata dan ekonomi kreatif di Pisang Island, Kabupaten Pesisir Barat, Provinsi Lampung. Tujuan dari penelitian ini adalah untuk menganalisis sinergitas yang dilakukan oleh berbagai pihak dalam pengembangan wisata bahari di Pisang Island. Pendekatan penelitian yang digunakan adalah pendekatan kualitatif dengan tipe deskriptif. Teknik pengumpulan data yang digunakan adalah wawancara, dokumentasi dan observasi sedangkan analisis data dilakukan melalui reduksi data, pemaparan dan penarikan kesimpulan. Hasil penelitian diperoleh bahwa strategi pengembangan wisata bahari di Pisang Island tidak berjalan dengan baik tanpa sinergitas antar pemerintah, masyarakat dan investor. Pemerintah merupakan pihak perintis pembangunan fasilitas baik sarana dan prasarana utama demi terciptanya kemudahan bagi pencarian calon investor yang akan menanamkan modalnya. Rekomendasi dari penelitian ini yaitu bahwa Pemerintah daerah sebaiknya meningkatkan kegiatan penyuluhan dan pelatihan serta pendidikan masyarakat untuk menciptakan kesadaran masyarakat. Sedangkan pihak swasta dapat menanamkan modalnya dengan merintis pembangunan sarana yang belum ada untuk mewujudkan kenyamanan wisatawan.
\end{abstract}

Kata kunci: sinergitas; stakeholder; wisata bahari; daerah tertinggal

\section{Introduction}

Tourism has developed into a strategic sector besides mining. The natural beauty and cultural diversity of a nation are valuable assets that attract the attention of domestic and international tourists. Tourism based on some research, provided economic impacts for its people through employment especially marine ecotourism, (Hall \& Page 2006, Junaid 2017, Reindrawati 2017). The development of ecotourism is considered as a sustainable strategy generates positive economic benefits for local communitis (Adams et al 2004, Harrison and Schipani 2007, Spenceley and Goodwin 2007, World Tourism Organization 2012, Truong et al 2014, Adiyia et al 2017). According to Yulianda (2007) 
marine tourism is tourism activity prioritizes dynamics and underwater resources in the sea waters. Based on the Regulation Number 10 Year 2009 about tourism, stated that a wide range of tourism activities supported by various facilities and services provided by the community, businessmen, government and local government. Some of the steps taken by the government as an effort to develop the potential of natural tourism objects, among others, by giving counseling to the community around the attractions in maintaining and preserving the environment also establish cooperation with private parties. Governments and local governments are required to provide tourism for the community as an effort to meet the needs of physical, spiritual, intellectual and to increase state revenues for realizing the welfare of society. The government's effort was inspired by the study about resident perceptions of the impact in tourism. The impacts had focused on three categories of benefits and costs 1) Economic, such as increasing job opportunity, income, inflation and tax, 2) Socio-cultural, such crowds, crime and community image awareness of cultural pride and heritage also improvement of cultural facilities, 3) Environmental such as wildlife destruction, pollution and improvement of local infrastructur, (Pin Yu et al 2014). Tourism development also can maintain essential ecological processes and help conserving the natural and man-made heritage as well as biodiversity as Atun Alpar et al (2018) also stated that sustainable tourism could ensure long-term economic operations, providing socio-economic benefits to all stakeholders including 1) Stable employment, 2) Income opportunities and 3) Social services to host community.

Tourism according to the regulation has become a necessity for the community. So the management must be done seriously and involving the parties concerned, in addition to achieve all the tourism development goals. The service is also important to visitors in addition to infrastructure. The tourism development is not a short-term results, but long-term sustainability with planning and support from all stakeholders. Each stakeholders had the activities and programs that brings positive impact on tourism development (Bibin et.al 2018). The tourism management planning is determined by the balance of natural resources and the services in tourism objects. Each tourism area requires a management plan contains the targets in the future. The management should contain the objectives, actions and finacial for tourism development goals (Djunaedi 2011). According to Tuwo (2011) that management planning must have a guide for stakeholders in every management activities. Another research from sustainable rural tourism in Cyprus found that the research provided groundwork for long-term tourism management on developing strategies, policies on future sustainable development forecasting, (Atun Alpar et.al 2018). Tourism development is sustainable if planned strategically in achieving the goals that were manifestated theirs effects over the long term (Fons et.al 2011). Sustainability has become essential element of tourism development in general (Aronsson 2000; Bramwell \& Lane 1993, Bramwell et.al 1998, Butler 1999, Garrod \& Fyall 1998, Goodal \& Stabler 1997, Inskeep 1991, United Nations 2001, Wahab \& Pigram 1997).

The development of tourism is related to the preservation of national culture, through the utilization of the potential of beauty and natural wealth. Utilization does not mean totally change, but manage, develop, utilize and preserve existing potential. Potential is used as a tourist attraction. Therefore, the management, development and utilization of tourism potential owned by the region is also managed by each region. So is the case with Lampung Province, where Lampung Province has many potential and natural resources that can be developed as a tourist attraction. There are lots of potential marine tourism besides Pisang Island such as Tomini Bay that were constantly contested among various actors such as private entities, the state, and multilateral institutions because of the abundant coastal and marine resources (Obie 2018). According to this research, Bajo Tribe utilised coastal and marine resources as a livelihood based while private entities with the permits from the state maximized the economic benefits. Another research about potential culture as a tourist attraction was in Kelud Mountain from Alfath and Permana (2016). Their reseach concluded that convening "Festival 1000 Tumpeng" could preserve the traditions and promote the tourism.

Based on Tourism Development Master Plan of Lampung Province in 2012-2031, seven areas of excellence tourism are included: 1) Leading tourism area of Bandar Lampung, 2) Leading tourism area of Krui and Tanjung Setia, 3) Way Kambas National Park, 4) Leading tourist area of Kiluan 
Bay, 5) Leading tourist area of Mount Anak Krakatau and Sebesi Island, 6) Leading tourist area of Bakauheni and Siger Tower, and 7) Leading tourist area of Bukit Barisan Selatan National Park.

Lampung Province geographically has a strategic location due to the gate of Sumatra Island. This province has a variety of tourist destinations that have great potential to be developed. This highly promising a potential tourism, if managed and developed properly, will provide benefits for Lampung Province. Natural potential of this province is located in coastal areas, one of them in Kabupaten Pesisir Barat. Natural landscape features are the key attraction for the visitors (Larson \& Herr 2008) and the destinations rely on nature as the main tourist attractions (Cater 1996, Hochtl et.al 2005, Hudson \& Miller 2005, Lynn \& Brown 2003, Ross \& Wall 1999).

Pesisir Barat District has great potential natural spot, one of them is Pisang Island. Besides listed as one of the leading tourist area in Lampung Province in Tourism Development Master Plan, in the Regulation of Lampung Number 6 Year 2011 Article 11 About Tourism, Krui Maritime Tourism Area (Pisang Island.) is also one a strategic area of six tourism areas. a priority to be developed. We can see the dolphins, beautiful beaches and marlin fish here. Not only in Lampung Province, many other regions in Indonesia have great potential tourist attractions with the unique natural beauty such as Sota District in Merauke that is famous for its agricultural product like fruits and vegetables also the twinmonuments of Sabang and Merauke (Dewi \& Rachmawati 2018). Other regions in Indonesia that is rich for tourism potential is located in East Java named Batu City. It is famous for the agriculture from the region (Sukmana 2007).

Pisang Island is located in coordinates: $05^{\circ} 02$ ' 52 "South Latitude and $103^{\circ} 45^{\prime}$ ' 01 " East Longitude. This area has an area of $64,00 \mathrm{~km}^{2}$ or 2,20 of West Coast District area. This subdisrict area is mostly used for plantation land while the rest is divided into various designations, such as residential areas, public facilities, tourism, fisheries and others. This picture shows the characteristics of the territory that is agrarian. Pisang Island is dominated by plantation and fishery activities (Source: R \& D of Bappeda Kabupaten Pesisir Barat, 2015).

Pisang Island has the uniqueness beauty of the beach and shape of the island. The location of this area is occupied by marine mammals such as dolphins, marlin fish and other marine habitats. But there are not many visitors who want to visit this tourism spot. It was mostly because of its remote islandshaped area with inadequate infrastructure, long distance traveled by small boats and its territory had not been powered by electricity (Source: Dinas Pariwisata dan Ekonomi Kreatif 2015). Tourism is often beneficial for the development of its destination regions but that alone does not make it sustainable (Saarinen 2006). Saarinen (2006) argues that development of tourism may not always be the most favorable use of natural and cultural resources and might create unsustainable trajectories for both host communities and habitats. It is important to create the plan at the appropriate scale and resolution as the research from (Larson \&Herr 2008) in Kimberley Region, Autralia. Kimberley is a remote tourism area in Australia. The survey of visitors to The North Kimberly region has highlighted important data about the origin of visitors, purpose of the visit, mode of travel and motivation for visitation have implications for future regional tourism planning,

\section{Research Method}

The type of research used was descriptive research type with a qualitative approach. This research was aimed to describe and explain and the symptoms contained in the problem of empirical events in the Implementation Strategy of Tourism and Creative Economy Department througth the the synergy among stakeholders.

The focus of this research was the synergy among stakeholders to develop Pisang Island as a Marine Tourism in Underdevelopped Areas. Data collection techniques used were interviews, documentation and observation. According to Sugiyono (2009:244), data analysis is the process of searching and compiling systematically the data obtained from interviews with related parties from Tourism and Economic Creative Department of Pesisir Barat, Regional Planning And Development Department 
in Pesisir Barat, and Sukadana Apparatus as the location where Pisang Island located. These parties are important as the key informants that provide lots of information. Other techniques used for data collection were field notes and documentation by organizing data into categories, describing into units, synthesizing, compiling into patterns, choosing the important datas which will be learned and making the conclusions.

\section{Results and Discussion}

Tourism Development of Pisang Island based o Tourism Development Master Plan of Lampung Province in 2012-2031 was focused on: 1) Analysis of the development of leading tourist areas of Pisang Island covers the aspects of tourism object, supporting facilities, infrastructure, environment, marketing, transportation, 2) The feasibility analysis of the development of Pisang Island were: technique feasibility analysis, market feasibility analysis, management feasibility analysis, investment feasibility analysis, 3) Physical development guidance of the leading tourist areas of Pisang Island, including: strategy and concept of development and spatial planning area, planning activities, equitable development, transportation development plan and development plans of infrastructures. Meanwhile the Creative Economy Development Plan on Pisang Island was focused on: 1) Home idustry of Abon fish, 2) Home idustry of Banana Chips, 3) Home industry of Cassava Chips, 4) Encouraging the development of regional specialties (culinary icons) namely: iwak pelus, iwak winding, pandap, and 5) Encouraging tapis clothe or handmade from local industry.

The synergy among government, society and private party concerning marine tourism development strategy in Pisang Island

\section{Government}

The government has an important function to develop Pisang Island. Because the government implement the development, tourism activities can not be separated from the role of government both central government and local government. The government is responsible for four matters: the planning of the area, the development of major tourism, the policy of tourism, also the establishment and enforcement of regulation.

Government responsibility is creating the plan or strategy defined by David (2009:4). It is the determination of long-term goals and objectives that are fundamental for all organizations followed by the determination of activity plans and the allocation of esources needed to achieve the goal. In this case the local government of Pesisir Barat shoud make the plans to build the facilities near Pisang Island as infrastructure development, find the investors to create the business in this area, allocate the budget for the development of infrastructures, promote potential tourist attraction in Pisang Island through the website and other medias to achive the goal for developing tourism in remote area. Finally it is also important for creating the awarness of people near Pisang Island as the host community. They must know and realize potential tourism attraction of their region to other regions, nationally and internationally.

Based on interview data from Tourism and Creative Economic Department of Pesisir Barat obtained the information about the important use of social media to promote tourism. The government performed its role as a provider of internet infrastructure and facilities. From this information menas the government shouuld be aware of the development of electronic commerce (E-commerce) has led to great changes in the tourism industry in many countries around the world. Global economy is entering into digital economy, the information time, information economy, cyber economy that gradually become the trend in economic development. As the main economy, e-business will bring great innovation to all countries and become the great motivation of economy and a new growth point, (Jin and Xu 2007). In China, The Chinese tourism industry has invested large amounts of money over last few years in the development of what is known as The "Golden Tourims Project. This study sheds more light on the project by investigating online tourism service development in China from three perspectives: the tourism website, the tourism website user and the tourism 
website provider. The results show that the majority of tourism website providers are regional tourism destination organizations that mainly provide comprehensive local tourism information and online services. The results also show the level of regional economic has a significant impact on the construction of these local tourism website, (Lu \& Lu 2004). According to Jin and Xu (2007) that the tourism enterprises are new business activities linked through computer technology, electronic communication technology and enterprise buying and selling network system that based on internet technology provided by internet. They are three points of necessity of development of tourism e-business 1) Market competition, 2) Tourist enterprises, and 3) Customers.

From the data above showed that the government participate in the development of marine tourism in Pisang Island by supporting internet. First the government played a role in supporting facilities and infrastructure in Pisang Island. Second, the government played a role in building public awareness on Pisang Island by giving counseling and training as well as promotional activities through social media altough the efforts done by the local government have not been maximized.

\section{Society}

The community in Pisang Island does not play an active role in the development of marine tourism. They are considered not to have full awareness. According to the research data from Tourism and Creative Economy of Kabupaten Pesawaran showed that the community was still difficult to cooperate in the development of the region. The community was less active in its role due to the lack of awarness on tourism. In addition, they were more focused on their daily activities such as farming or fishing. Their earnings in faarming and fishing were more than tourism sector.

The development of tourism according to Yoeti (2008:273) is a business or a way to advance and develop something that already exists. Tourism development in a tourist destination will always be taken into account with the benefits for the surrounding community. The development of tourism must be in accordance with the mature planning so as to give the benefit for the community, both economically and social. By looking at the existing cases on Pisang Island about less awareness, it was found that the community did not have the facilities they needed, tourism activities had not yet benefited economically and socially.

\section{Investors}

Investors are expected to provide funds for development to run optimally. According to data from Reginal Development Board of Pesisir Barat District, it was found that there was no investor who wanted to invest in Pisang Island. It makes the government of Kabupaten Pesisir Barat has the efforts continuously to find interested and potential investors. To attractnthe potential investors, the government must make the profile of the nature in Pisang Island. From the data obtained in our research, this was the picture of the beach of Pisang Island that is seen in Figure 1.

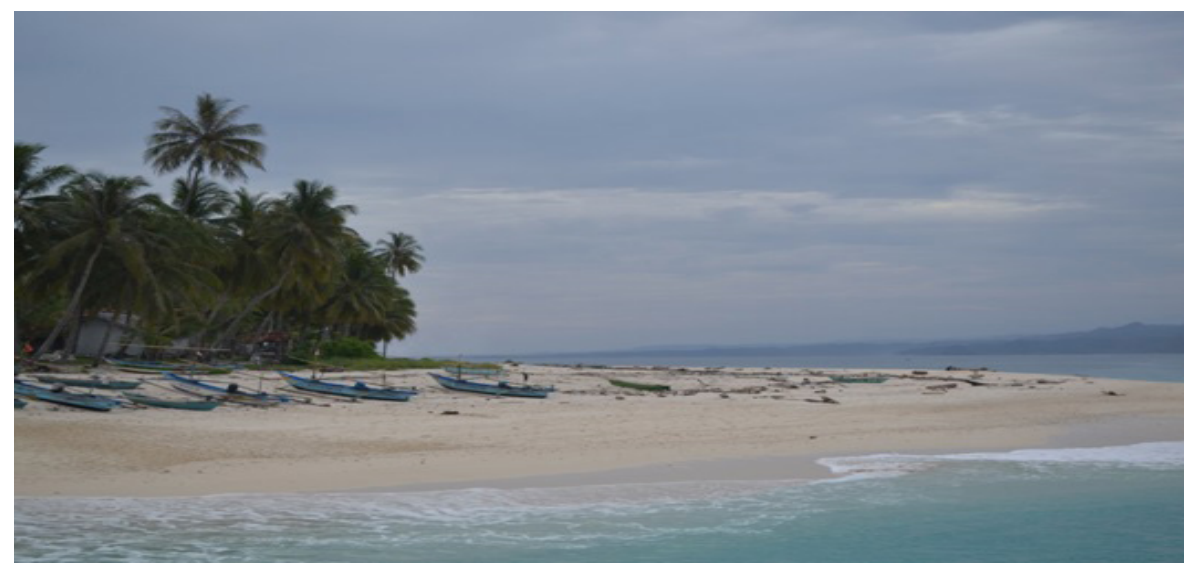

Figure 1.

The condition of Pisang Island 
Based on the data above, investors have an important role in tourism development strategy such as: 1) Providing the funds, 2) Building and developing the facilities, 3) Promoting the tourism.

In Figure 1, there was a lack of infrastructure in Pisang Island. According to Suwantoro in Pitana (2005:70), the main elements that must be paid attention to support tourism development in tourist destination areas include: 1) Object or tourist attraction is a potential that encourages the presence of tourists to a tourist destination, 2) Infrastructure is a natural resource and man-made resources that are absolutely needed by tourists on their way in tourist destinations, such as roads, electricity, water, telecommunications, terminals, bridges and so on, 3) Facility is the completeness of the tourist destination that is needed to serve the needs of tourists in enjoying the tour. Various tourist facilities that must be provided in tourist destination are hotel, travel agency, transportation, restaurant and other supporting facilities.

In Figure 1, the beach of Pisang Island had not have the supporting facilities in the area such as hotels, cottages, restaurants, seaside seating facilities, surfing support activities, etc. This condition should be focused by the investors to invest their funds as the pioneer for others investors to develop the region. At present Pisang Island has not been taken seriously as a tourist destination. However, this island saves a variety of potential that can later become one of the leading tourist destinations in Lampung Province, both for local and foreign tourists. These potentials include the beauty of nature, land and sea, the customs of local communities that are still preserved, history, and woven weaving crafts that can be special interest tours. The remote area near Indonesia Ocean is one of the obstacle to reach the place. It has two famous traditional food from resident receipt such as (pepes) blue marine fish and tuwu fish wrapped in a banana leaf and roasted (Source: Pisang Island Profile from Tourism Departement of Kabupaten Pesisir Barat).

\section{Conclusion}

Synergy among stakeholders in developing the potential of marine tourism in Pisang Island, Pesisir Barat District can be done by collaborating among actors through communication links with various parties such as doing Focus Group Discussion (FGD) involving various stakeholders and trying to find solutions to the problems. The Local Government should increase the promotion of potential tourism in Pisang Island in the website, create programs or activities such as festivals to increase the of tourists, look for the funding from investors to invest their capital by facilitating business licensing processes, building infrastructure and creating tourism awareness group to improve socialization and build a creative economy for the development of the region.

\section{References}

Adams WM, Aveling R, Brockington D, Dickson B, Elliott J, Hutton J, Roe D, Vira B, \& Wolmer W (2004) Biodiversity conservation and the eradication of poverty. Science 306 (5699):11461149 .

Adiyia B, Vanesste D, Rompaey AV, \& Ahebwa WM (2014) Spatial analysis of tourism income distribution in the accomodation sector in Western Uganda. Tourism and Hospitality Research 14 (12):8-26.

Alfath ED \& Permana YS (2016) Festival 1000 tumpeng: Komodifikasi tradisi, pariwisata, dan ‘territoriality’di Gunung Kelud. Masyarakat, Kebudayaan dan Politik 29 (4):169-180.

Alpar AR, Hassina N, \& Ozlem OT (2018) Envisaging sustainable rural development through "Context-Dependent Tourism": Case of Northern Cyprus. Environment Development Sustain.

Aronsson L (2000) The Development of Sustainable Tourism. London: Continuum.

Bibin M, Vitner Y, \& Imran Z (2018) Analysis of stakeholder in the development of Labombo Beach sustainable town in Palopo City. Masyarakat, Kebudayaan dan Politik 31 (1):62-71. 
Bramwell B \& Lane B (1993) Sustainable tourism: An envolving global approach. J Sustinable Tourism 1:1-5.

Bramwell B, Henry I, Jackson G, Prat A, Richards G, \& van der Straaten J (1998) Sustainable Tourism Management: Principles and Practices, 2nd edn. Tilburg: Tilburg University Press.

Butler RW (1999) Sustainable tourism: A state-of-the-art review. Tourism Geographies 1 (1):7-25.

Cater EA (1996) Ecotourism in The Carribean : A Sustainable Option For Belize and Dominica?. In: L Briguglio, RW Butler, D Harrison, \& WL Filho (eds). Sustainable Tourism In Island \& Small States: Case Studies. Pinter Publisher. New York, 122-146.

David FR (2009) Konsep Manajemen Strategis. Jakarta: Salemba Humanika.

Dewi MA \& Rachmawati I (2018) The barriers and strategy of sota's border tourism development. Masyarakat, Kebudayaan dan Politik 31 (4):400-409.

Dinas Pariwisata dan Ekonomi Kreatif Kabupaten Pesisir Barat (2015) Dokumen Tahun 2015. Kabupaten Pesisir Barat.

Dinas Pariwisata dan Ekonomi Kreatif Kabupaten Kabupaten Pesisir Barat (2015) Rencana Strategi Dinas Pariwisata dan Ekonomi Kreatif Tahun 2015. Kabupaten Pesisir Barat.

Djunedi OS (2011) Sumber Daya Perairan Potensi Masalah Dan Pengelolaan. Bandung: Widya Padjajaran.

Fons MVS, Fierro JAM, \& Patino MG (2011) Rural tourism: A sustainable alternative. Applied Energy 88 (2):551-557.

Garrod B \& Fyall A (1998) Beyond the rhetoric of sustainable tourism?. Tourism Manage 19:199-212.

Goodal B \& Stabler MJ (1997) Principles Influencing The Determination of Environmental Standards for Sustainable Tourism. In: MJ Stabler (ed). Tourism and Sustainability. Principles to Practice. Oxford: CAB International, 279-304.

Hall CM \& Page SJ (2006) The Geography Of Toursim And Recreation. London: Routledge.

Harrison D \& Schipani S (2007) Lao tourism and poverty alleviation: Community-based tourism and the private sector. Current Issues in Tourism 10 (2-3):194-230.

Hochtl F, Lehringer S, \& Konold W (2005) "Wilderness": What it means when it bocomes a reality-a case study from the Southwestern Alps. Landsc Urban Plann 70:85-95.

Hudson S \& Miller GA(2005) The responsible marketing of tourism: The case of Canadian Mountain holidays. Tourism Manage 26:133-142.

Inskeep EL (1991) Tourism Planning: An Integrated And Sustainable Development Approach. New York: Van Nostrand Reinhold.

Jin Y \& Xu XS (2007) On Chinese tourism e-business development on current stage. IFIP International Federation for Information Processing, Volume 251. Integration And Innovation Orient To E-Society Volume 1. W Wang (eds). Boston:Springer, 586-592.

Junaid I (2017) Langkah strategis pengembangan indigeneos tourism: Studi kasus di Kepulauan Selayar. Masyarakat, Kebudayaan dan Politik 30 (3):266-277.

Junaid I \& Fauziah (2018) The carrying capacity for the development of marine ecotourism. Masyarakat, Kebudayaan dan Politik 31 (2):190-200.

Larson S \& Herr A (2008) Sustainable tourism development in remote region? Questions arising from research in North Kimberly Australia. Reg Environ Change 8:1-13.

Lu J \& Lu Z (2004) Development, distribution, and evaluation of online tourism services in China. Electronic Commerce Research 4:221-239. 
Lynn NA \& Brown RD (2003) Effects of recreational use impact on hiking experiences in natural areas. Landsc Urban Plann 64:77-87.

Obie M (2018) Exploitation of coastal and marine resources along Tomini Bay: Livelihood base versus concession rights. Masyarakat, Kebudayaan dan Politik 31 (1):36-45.

Peraturan Daerah Provinsi Lampung Nomor 6 Tahun 2011 Tentang Kepariwisataan.

Reindrawati DY (2017) Tantangan dalam implementasi socio entrepreneurship pariwisata di Pulau Madura. Masyarakat, Kebudayaan dan Politik 30 (3):215-228.

Ross S \& Wall G (1999) Ecotourism: Towards congruence between theory and practice. Tourism Manage 20:122-132.

Saarinen J (2006) Traditions of sustainability in tourism studies. Ann Tourism Res 33:1121-1140.

Spenceley A \& Goodwin H (2007) Nature-based tourism and poverty allevation: Impact of private sector and parastatal enterprises in and around Kruger, National Park South Africa. Current Issues in Tourism 10 (2-3):255-277.

Sugiyono (2009) Metode Penelitian Kuantitif Kualitatif. R dan D. Bandung: Alfabeta.

Sukmana (2007) Model Pengembangan Lingkungan Ekowisata. Universitas Muhamadiyah Malang.

Truong VD, Hall CM, \& Garry T (2014) Tourism and poverty alleviation: Perceptions and experiences of poor people in Sapa, Vietnam. Singapore Journal Of Tropical Geography 30 (3):388-403.

Tuwo A (2011) Pengelolaan Ekowisata Pesisir dan Laut: Pendekatan Ekologi, Sosial Ekonomi, Kelembagaan dan Sarana Wilayah. Surabaya: Brilian Internasional.

United Nations (2001) Managing Sustainable Tourism Development. ESCAP Tourism Review No 22. New York: United Nations.

Wahab S \& Pigram JJ (1997) Tourism, Development and Growth: The Challenge of Sustainability. New York: Routledge.

World Tourism Organization (2012) Annual Report 2011. Madrid: World Tourism Organization.

Yoeti OA (2008) Perencanaan dan Pengembangan Pariwisata. Jakarta: Pradnya Paramita.

Yu CP, Cole ST, \& Chancellor C (2016) Assessing community quality of life in the context of tourism development. Aplied Research Quality Life 11:147-162.

Yulianda F (2007) Ekowisata Bahari Sebagai Alternatif Pemanfaatan Sumberdaya Pesisir Berbasis Konservasi. Seminar Sains Pada Departemen Manajemen Sumberdaya Perairan. 21 Februari 2007. Bogor: Faculty of Fisheries and Marines Science, Bogor Agricultural Institute 